\title{
Leaf appearance of annual clovers responds to photoperiod at emergence
}

\author{
H. Nori ${ }^{\mathrm{a}, \mathrm{b}, *}$, D.J. Moot ${ }^{\mathrm{b}}$, A.D. Black ${ }^{\mathrm{b}}$ \\ a Faculty of Resource Science and Technology, University Malaysia Sarawak, Malaysia \\ ${ }^{\mathrm{b}}$ Faculty of Agriculture and Life Sciences, Lincoln University, PO Box 7647, Canterbury, New Zealand
}

\section{A R T I C L E I N F O}

\section{Article history:}

Received 24 February 2015

Received in revised form 5 October 2015

Accepted 11 October 2015

Available online 27 October 2015

\section{Keywords:}

Crop phenology

Growing degree-days

Trifolium vesiculosum

Trifolium michelianum

Trifolium glanduliferum

Trifolium resupinatum

\begin{abstract}
A B S T R A C T
Leaf appearance rate and time to canopy expansion of four annual clover species (arrowleaf, balansa, gland and Persian) were quantified in field and controlled environment studies. Crops sown in autumn, which experienced shortening daylengths at emergence, had a slower rate of leaf production and consequently took a longer time to initiate branching, than spring-sown crops. When autumn-sown 'Bolta' balansa clover emerged on the shortest day in winter (21 June), the rate of leaf appearance was lengthened by $4{ }^{\circ} \mathrm{Cd} /$ leaf/h. When the same species emerged after the shortest day, into an increasing photoperiod, the phyllochron was shortened by $5{ }^{\circ} \mathrm{Cd} / \mathrm{leaf} / \mathrm{h}$. This influence of photoperiod on the phyllochron consequently altered the time to axillary leaf production (branching). Throughout all sowing dates, phyllochron was the fastest for 'Prima' gland $\left(33-91^{\circ} \mathrm{Cd} / \mathrm{leaf}\right)$ and slowest for 'Cefalu' arrowleaf $\left(53-116^{\circ} \mathrm{Cd} / \mathrm{leaf}\right)$ clovers. 'Bolta' balansa was $44-82^{\circ} \mathrm{Cd}$ /leaf and 'Mihi' Persian $61-93^{\circ} \mathrm{C} \mathrm{d} /$ leaf. The response of phyllochron to photoperiod suggests these annual clovers should be sown in late summer or early autumn to initiate axillary leaf production as soon as possible to ensure maximize dry matter for early spring.
\end{abstract}

(C) 2015 Elsevier B.V. All rights reserved.

\section{Introduction}

In most annual crops, the rate of leaf appearance (phyllochron) and then their expansion on the primary stem affects canopy expansion and can influence the time to first flower. Predominantly, research on annual crops has focussed on leaf appearance in the major cereals and leaf appearance has been used as a descriptor to quantify the time to flowering (Jamieson et al., 1995; Sonego, 2000). This is because anthesis marks the switch from vegetative to reproductive development and the duration of grain filling commences at anthesis. Therefore, yield predictions in many computer simulation models are based on predicting flowering dates and the accumulation of thermal time post-anthesis.

For annual pasture clovers, the emphasis has also been on predicting time of flowering (Evans, 1959; Evans et al., 1992) because this marks the initiation of seed set which is essential for regeneration of the species in subsequent years. A recent study showed that floral initiation of annual clovers occurred after a specific number of nodes appeared on the main stem, and that this phenology differed with the time of planting (Nori et al., 2014). Flower induc-

\footnotetext{
* Corresponding author at: Faculty of Resource Science and Technology, University Malaysia Sarawak, Malaysia. Fax.: +60 82581360.

E-mail address: nhollena@frst.unimas.my (H. Nori).
}

tion was predominantly controlled by temperature and modified by photoperiod at seedling emergence. However, for annual forage crops, leaf appearance is also important for consumption and competitive ability in establishment of mixed pasture swards.

Specifically, the time to the first axillary leaf production (branching) is a key development phase because it indicates the time when the number of leaves and total leaf area increases exponentially. The canopy of leaves then allows the pasture species to compete strongly for light. The success or failure of a species can depend on the time taken to initiate branching. For example, the extended time required for Caucasian clover (Trifolium ambiguum) to produce its first axillary leaf $\left(1180^{\circ} \mathrm{Cd}\right)$ compared with the $440^{\circ} \mathrm{Cd}$ for white clover (Trifolium repens) and $373^{\circ} \mathrm{Cd}$ for perennial ryegrass (Lolium perenne) means it is a poor competitor in a sward. This has limited its adoption as a pasture species (Black et al., 2006).

Leaf appearance rate is often reported to be consistent irrespective of the time of planting (Hotsonyame and Hunt, 1997; Jamieson et al., 1995; Miglietta, 1989; Slafer and Rawson, 1997) and to be solely driven by the temperature at the growing point (Peacock, 1975). Jamieson et al. (1995) suggested that discrepancies of phyllochron with sowing dates were due to a mismatch between the measured temperature and the site of temperature perception. Other researchers suggest that inconsistencies of leaf appearance rate with time of sowing were attributed to photoperiod at the location of planting (Baker et al., 1980; Brown et al., 2005; Sonego, 